Jerzy Dygdała*

\title{
O początkach firmy piernikarskiej Weese, transporcie miodu i nadgorliwych celnikach w 1767 roku
}

\section{On the Beginnings of Weese Gingerbread Company, Transport of Honey and Overeager Customs Officers in 1767}

Über die Anfänge der Lebkuchenfirma Weese, über den Transport von Honig und die übereifrigen Zöllner im Jahr 1767

\begin{abstract}
Streszczenie. W artykule przedstawiono początki działalności toruńskiej firmy piernikarskiej Johanna Weese w połowie XVIII w. (obecnie Fabryka Cukiernicza KOPERNIK S.A.) oraz incydent, do którego doszło jesienią 1767 r., kiedy to na komorze celnej pod Brodnicą skonfiskowano, pod zarzutem nieopłacenia cła, 6 beczek miodu zakupionego przez Weesego w ziemi dobrzyńskiej. Na skutek interwencji toruńskiego rezydenta na dworze królewskim w Warszawie Samuela Luthra Gereta w Komisji Skarbu Koronnego cofnęła ona decyzję o konfiskacie miodu, zobowiązując Weesego do zapłacenia podwójnego cła.
\end{abstract}

\footnotetext{
* Pracownik naukowy Zakładu Historii Pomorza Instytutu Historii PAN. Prowadzi badania nad historią polityczną Polski epoki saskiej (zwłaszcza bezkrólewia 17331734 i pierwszego panowania króla Stanisława Leszczyńskiego 1704-1709), a także nad dziejami Prus Królewskich i Torunia w XVII-XVIII w., w tym nad historią społeczną i życia codziennego. Współautor wielotomowej „Historii Torunia”. Adres mailowy: jdygdala@ihpan.edu.pl; ORCID: 0000-0002-9704-6745
} 


\begin{abstract}
The article presents the beginnings of the Torun gingerbread company of Johann Weese in the mid-18th century (currently Fabryka Cukiernicza KOPERNIK SA) and an incident which took place in the autumn of 1767 , when 6 barrels of honey were confiscated at the customs chamber near Brodnica on the charge of Weese not paying customs duty in the Dobrzyń region. As a result of the intervention at the in the Commission for the Crown Treasury by Samuel Luther Geret, a resident of Torun at the royal court in Warsaw, the decision to confiscate the honey was reversed, obliging Weese to pay double duty.
\end{abstract}

Zusammenfassung. Im Artikel wurden die Anfänge der Thorner Lebkuchenfirma Johann Weese um die Mitte des 18. Jh. (heute Fabryka Cukiernicza KOPERNIK SA) und ein Zwischenfall vom Herbst 1767 präsentiert, als in der Zollkammer bei Strasburg/Brodnica 6 Fässer Honig, die von Weese im Dobriner Land gekauft wurden, wegen des Verdachts der Nichtbezahlung der Zollabgaben beschlagnahmt wurden. Infolge der Vorsprache des Thorner Residenten am Warschauer Königshof, Samuel Luther Geret in der Kommission für die Kronschatzkammer wurde sie die Entscheidung über die Honigbeschlagnahme zurückgenommen, indem aber Weese zur Zahlung der Zollabgaben in doppelter Höhe verpflichtet wurde.

Słowa kluczowe: toruńskie pierniki, piernikarska firma Johann Weese, transport miodu w 1767 r., spory o opłacenie cła

Keywords: Toruń gingerbread, Johann Weese gingerbread company, transport of honey in 1767 , customs duty payment disputes

Schlüsselwörter: Thorner Lebkuchen, Lebkuchenfirma Johann Weese, Transport von Honig im Jahre 1767, Streitigkeiten über Zahlung von Zollabgaben

Bardzo dawno temu, zbierając materiały do pracy doktorskiej, mozolnie sporządzałem wypisy z korespondencji toruńskiego rezydenta na dworze królewskim w Warszawie, Samuela Luthra Gereta, z władzami miasta. Obok ważnych kwestii politycznych i ekonomicznych dotyczących m.in. zatwierdzania przywilejów miejskich, sporów o cło generalne, udziału w sejmikach generalnych Prus Królewskich czy poszerzenia praw wyznaniowych polskich różnowierców i zagrożenia 
ze strony konfederacji barskiej, poruszano w tych listach także sprawy jednostkowe, wymagające interwencji rezydenta w centralnych organach administracyjnych ówczesnej Rzeczypospolitej. Wśród sporządzonych wtedy fiszek znalazła się też notatka o niesłusznej konfiskacie transportu miodu przeznaczonego dla toruńskiego piernikarza Weesego. Ta drobna sprawa nie została poruszona w mojej książce doktorskiej ${ }^{1}$, choć później niejednokrotnie przypominałem sobie o tej informacji.

Nie tak dawne otwarcie obszernego Muzeum Toruńskiego Piernika w budynkach byłej fabryki pierników Gustawa Weesego przy ul. Strumykowej i ukazanie się znakomitej monografii Joanny Kucharzewskiej poświęconej dziejom tej piernikarskiej familii ${ }^{2}$, skłoniły mnie do dokładniejszej analizy tego przypadku, związanego z samymi początkami tej firmy, noszącej obecnie nazwę „Fabryka Cukiernicza KOPERNIK S.A.”. Z literatury wiadomo, że Johann Weese, urodzony w Toruniu 1 czerwca 1731 r., poślubił w 1761 lub w 1763 r. Dorotę Schreiber, wdowę po mistrzu piernikarskim Johannie Samuelu Schreiberze młodszym. Tenże Johann Weese był synem Gottfrieda, konwisarza przybyłego do Torunia z Gdańska, i Christiny z domu Glaser, wdowy po toruńskim konwisarzu Ernście Gottfriedzie Meydingu ${ }^{3}$.

Warto jednak sięgnąc bezpośrednio do źródeł w celu uzyskania bardziej szczegółowych informacji o pochodzeniu rodziny Weese. Ze sporządzonego w Gdańsku 5 grudnia 1714 r. świadectwa dobrego urodzenia Gottfrieda Weesego wynika, że był on synem gdańszczanina Michaela Weesego, pracownika (robotnika - Arbeitsmann) w tamtejszym Urzędzie Budowlanym (Bau-Ambt), i Marii z domu Nickels. Według informacji zasłużonego toruńskiego historyka Artura Semrau'a najstarsze gdańskie wzmianki o rodzinie Weese pochodzą z około 1690 r., przy czym dziadek Gottfrieda był strażnikiem leśnym w jednej ze wsi należących do Gdańska, a samo nazwisko jest pocho-

\footnotetext{
1 J. Dygdała, Polityka Torunia wobec władz Rzeczypospolitej w latach 1764-1772, Warszawa-Poznań-Toruń 1977.

${ }^{2}$ J. Kucharzewska, Historia rodziny Weese - fabrykantów toruńskich pierników i jej inwestycje budowlane w Toruniu, Toruń 2017.

${ }^{3}$ Ibid., s. 24, tam też dawniejsza literatura.
} 
dzenia dolnoniemieckiego i pierwotnie brzmiało Wiese ${ }^{4}$. W momencie sporządzania tego dokumentu Gottfried Weese był jeszcze stanu wolnego. Nie wiemy dokładnie, kiedy Gottfried Weese przeniósł się do Torunia, ale 3 września 1728 r. przedstawił to gdańskie świadectwo dobrego urodzenia toruńskiej Radzie i otrzymał obywatelstwo miejskie jako konwisarz (Zinngießer). Jest rzeczą charakterystyczną, że w gdańskim dokumencie zapisano nazwisko zarówno ojca, jak i syna w formie Wehse ${ }^{5}$, natomiast w toruńskiej księdze przyjęć do prawa miejskiego zapisano go jako „Gottfried Weise, ein Ziengieser aus Dantzig”, po czym w nazwisku skreślono literę „i”, tak więc brzmiało ono Wese. W indeksie osobowym do tej księgi (sporządzonym później, ale jeszcze w XVIII w.) figuruje on pod nazwiskiem Weisse $^{6}$. Świadczyć to może o niestabilności ostatecznej formy tego nazwiska, które dopiero w Toruniu przyjęło formę Weese.

Nie wiemy dlaczego syn Gottfrieda, Johann, nie poszedł w ślady ojca i nie zajął się metalurgią (konwisarstwem), ale 26 kwietnia $1747 \mathrm{r}$., w wieku 16 lat, został przyjęty na naukę zawodu piekarza-piernikarza do mistrza Melchiora Friebe ${ }^{7}$. Tenże piernikarz pochodził ze wsi Nieder Laufensdorf ${ }^{8}$, przypuszczalnie z Żuław Malborskich ${ }^{9}$. Prawo miejskie w Toruniu uzyskał 14 grudnia 1718 r. i już wtedy miał w Toruniu swoją kamienicę, wraz z dużym warsztatem piernikarskim zatrudniającym okresowo 7-8 osób, przy obecnej ul. Różanej 1 (na rogu ul. Ducha Św.). Od roku 1745 aż do śmierci był członkiem III Ordynku. Johann

${ }^{4}$ A. Semrau, Die Thorner Pfefferküchler, Mitteilungen des Coppernicus-Vereins für Wissenschaft und Kunst zu Thorn, H. 46: 1938, s. 129.

${ }^{5}$ Archiwum Państwowe w Toruniu, Akta miasta Torunia, Katalog III (dalej cyt. APTor.), nr 5028, świadectwo dobrego urodzenia Gottfrieda Wehse, Gdańsk 5 XII 1714.

${ }^{6}$ APTor., Katalog II, I 55, księga przyjęć do prawa miejskiego, s. 72, wpis z 3 IX 1728 , s. 377 indeks.

${ }^{7}$ J. Kucharzewska, op. cit., s. 24, autorka zwraca uwagę, że w znacznej części literatury nazwisko to występuje w formie (błędnej) - Friese.

${ }^{8}$ APTor., Kat. II, I 55, s. 16, wpis z 14 XII 1718; A. Semrau, op. cit., s. 125.

${ }^{9}$ K. Mikulski, Pułapka niemożności. Spoteczeństwo nowożytnego miasta wobec procesów modernizacyjnych (na przyktadzie Torunia $w$ XVII i XVIII wieku), Torun 2004, s. 91. Inna rzecz, że miejscowości o takiej, albo podobnej, nazwie nie odnotowuje S. Rospond, Stownik nazw geograficznych Polski zachodniej i pótnocnej, Wrocław-Warszawa, 1951, t. 2. 
Weese po czterech latach terminowania został 30 kwietnia 1751 przyjęty jako czeladnik do bractwa piernikarskiego, a 5 września 1760 uzyskał, jako „Johann Wese ein Pfefferküchler” (piernikarz), prawo miejskie i tytuł mistrza ${ }^{10}$. Jego nauczyciel i mistrz Melchior Friebe zmarł 28 grudnia 1757 r. $^{11}$, a młody Weese ożenił się, zapewne w 1760 r., $\mathrm{z}$ wdową po nim Elżbietą (Elisabeth) z domu Lorentz. W ten sposób objął we współposiadanie kamienicę i zakład piernikarski. Jego żona zmarła jednak już około 1762 r. i Johann Weese został jednym z jej dwojga spadkobierców. Drugim była córka (lub bliska krewna) Elżbiety Friebe, Dorota Elżbieta Mędzikowska, oraz jej mąż (drugi?), kupiec Jan Krzysztof Cieracki, którzy ostatecznie w 1763 r. zostali jedynymi właścicielami tej nieruchomości ${ }^{12}$.

Rok później, 14 lutego 1763 r. Johann Weese ożenił się ponownie. Jego wybranką znowu była wdowa po piernikarzu, Dorota (Dorothea) Konkordia Schreiber z domu Conradt (Conrad), córka toruńskiego sukiennika i kupca Adama Conrada ${ }^{13}$. Jej mąż, Johann Samuel Schreiber młodszy, zmarł 12 marca $1761 \mathrm{r}$. w wieku zaledwie 30 lat, pozostawiając jej spory warsztat piernikarski (zatrudniający 6-7 czeladników) i kamienicę ${ }^{14}$. Rodzina Schreiberów wywodziła się z Saksonii z miasta Annaberg na północ od Chemnitz. Stamtąd też przybył do Torunia Johann Samuel starszy, który 31 maja 1726 r. otrzymał tu prawo miejskie i po ożenieniu się 2 lipca tegoż roku z Dorotą (Dorotheą) $\mathrm{z}$ domu Merckner (zmarłą 24 maja 1744 r.), wdową po mistrzu piernikarskim Johannie Christophie Hafft ${ }^{15}$, został przyjęty do cechu piekarzy chleba białego i ciastkarzy (Loß- und Kuchenbecker) ${ }^{16}$. Już 24 maja 1730 r. wybrano go do Trzeciego Ordynku, współrządzącego mia-

\footnotetext{
${ }^{10}$ J. Kucharzewska, op. cit., s. 24; APTor., Kat. II, I 54, s. 108/109, wpis do księgi przyjęć do prawa miejskiego z 5 IX 1760.

11 J. Dygdała, Urzędnicy miejscy Torunia. Spisy, cz. III: 1651-1793, Toruń 2002, s. 181, nr 957.

${ }^{12}$ Zob. przypis 10 (księgi pogłównego z lat 1760-1763).

13 APTor., Akta Ewangelickiej Gminy Wyznaniowej Nowomiejskiej (dalej cyt. EGWN), t. 77, s. 304. A. Semrau, op. cit., s. 129.

${ }^{14}$ K. Mikulski, op. cit., s. 94; A. Semrau, op. cit., s. 129.

${ }^{15}$ K. Mikulski, op. cit., s. 94.

${ }^{16}$ APTor., Kat. II, I 55, s. 64, wpis do księgi przyjęć do prawa miejskiego z $31 \mathrm{~V}$ 1726.
} 
stem $^{17}$. Firma dobrze prosperowała, bo najpóźniej w kwietniu 1733 r. (a może już w 1730 r.?) Schreiber kupił kamienicę przy ówczesnej Schmergasse 11 (Siodlarskiej), czyli obecnej ul. Królowej Jadwigi nr 20A. Zabudowania gospodarcze (w tym spichrz) na tyłach tej kamienicy sięgały z jednej strony do ul. Strumykowej, z drugiej do ul. Małe Garbary ${ }^{18}$. Schreiber został też 30 marca 1740 r. ławnikiem nowomiejskim. Po jego śmierci w początkach grudnia 1750 r. (pogrzeb nastąpił 5 grudnia) ${ }^{19}$ majątek ten odziedziczył jego syn Johann Samuel młodszy, urodzony 6 stycznia 1731 r., który formalnie uzyskał prawo miejskie w Toruniu 30 grudnia 1750 r. ${ }^{20}$ Część spadku przejął jednak, wraz z ręką wdowy, Johann Weese. Od tego momentu prowadził działalność wyłącznie pod swoim nazwiskiem. Już wówczas była to największa firma piernikarska w Toruniu ${ }^{21}$. W marcu 1763 r. Johann Weese wraz z żoną zatrudniał 6 osób, w tym 2 czeladników $^{22}$. We wrześniu 1764 r. doszła jeszcze jedna dziewka służebna ${ }^{23}$. W marcu 1767 było tam już 8 osób, w tym 3 czeladników i 2 dziewki służebne ${ }^{24}$. W dobie niepokojów konfederacji barskiej, kiedy miasto odczuwało skutki konfederackiej blokady i ponosiło koszty utrzymywania rosyjskiego garnizonu, działalność firmy piernikarskiej Weesego uległa pewnemu ograniczeniu. W marcu 1769 r. zatrudniał on 7 osób, w tym 2 czeladników, a we wrześniu tegoż roku jedynie 6 osób, w tym tylko jednego czeladnika ${ }^{25}$.

O skali interesów Johanna Weesego dobrze świadczy incydent, którym musiały zajmować się najwyższe władze skarbowe Rzeczypo-

\footnotetext{
17 J. Dygdała, Urzędnicy miejscy Torunia, s. 176, nr 902.

${ }^{18}$ K. Mikulski, op. cit., s. 94, przypisy 283 i 284; zob. też plan Socjotopografia Starego i Nowego Miasta Torunia w 1703 r. w pracy tegoż Przestrzeń $i$ spoleczeństwo Torunia od końca XIV do początku XVIII wieku, Torun 1999; J. Kucharzewska, op. cit., s. 22.

19 J. Dygdała, Urzędnicy miejscy Torunia, s. 130, nr 447; K. Mikulski, Pułapka niemożności, s. 94.

${ }^{20}$ J. Kucharzewska, op. cit., s. 22-23, tabela 1; APTor., Kat. II, I 54, s. 88, wpis do księgi przyjęć do prawa miejskiego z 30 XII 1750

${ }^{21}$ K. Mikulski, Pułapka niemożności, s. 94.

${ }^{22}$ APTor., Kat. II, XVI 4, Księga pogłównego 1763, s. 750.

${ }^{23}$ Ibid., XVI 19, Księga pogłównego 1764, s. 150.

${ }^{24}$ Ibid., XVI 20, Księga pogłównego 1767, s. 367.

${ }^{25}$ Ibid., XVI 21, Księga pogłównego 1769, s. 119, 357.
} 
spolitej. Sekretarz toruńskiej Rady Miejskiej Johann Teodor Elsner 21 października 1767 r. powiadomił rezydenta Torunia na dworze królewskim w Warszawie Samuela Luthra Gereta, że przed kilkoma dniami pod Brodnicą jacyś urzędnicy celni zatrzymali dwa wozy z miodem należące do czcigodnego pana Wese[!] i zażądali opłacenia cła od tego ładunku. Elsner powiadomił swego kolegę, że zapewne trzeba będzie $\mathrm{w}$ tej sprawie interweniować $\mathrm{u}$ odpowiednich władz, a tymczasem przesyła mu, sporządzony w Toruniu, protokół z przesłuchania obu woźniców, którzy prowadzili wozy Weesego i objaśnili przebieg tego incydentu ${ }^{26}$.

O tym co się działo pod Brodnicą w Toruniu wiedziano już nieco wcześniej, bo 16 października 1767 r. Rada tegoż miasta poskarżyła się Radzie Torunia, że celnicy zajęli stanowiska w miejskiej karczmie (na przedmieściu), utrudniają przejeżdżającym wjazd do miasta, są natrętni wobec podróżnych i sprawiają im wiele kłopotów, o czym Rada Torunia może się dokładniej dowiedzieć od woźniców powożących wozami piernikarza (Weesego ${ }^{27}$.

S. L. Geret po otrzymaniu informacji z Torunia natychmiast interweniował u odpowiednich władz. Ponieważ zgodnie $\mathrm{z}$ uchwałami sejmów z 1764 r. służby celne podlegały nowo utworzonej Komisji Skarbu Koronnego ${ }^{28}$, toruński rezydent przedłożył jej, w imieniu Rady Torunia, memoriał zawierający skargę na postępowanie celników. Komisja, nie zwlekając, zajęła się tą sprawą i już 2 listopada $1767 \mathrm{r}$. pojęła następującą decyzję: „Komisja na memoriał szlachetnego Geret sekretarza, imieniem miasta Torunia podany, rezolucję dała, iż sześć

${ }^{26}$ APTor., Kat. II, 3365, s. 569/570, J. T. Elsner do S. L. Gereta, Toruń 21 X 1767; niestety nie zachował się załącznik z zeznaniami obu woźniców.

${ }^{27}$ APTor., Kat. II, 3365, s. 921, Rada Brodnicy do Rady Torunia, 16 X 1767 ( „... was wir vor Beeinträchtigungen von denen Reichs-Zollbedienten erdulden müßen; diese haben sich in unseren Stadtkruge postiret, verwahren denen Reisenden die Einfahrt, attaquiren die Vorbeifahrenden und machen ihnen und uns vielen Verdruß...". Kopię tego listu także przesłano Geretowi do Warszawy.

${ }_{28}$ Zob. szerzej R. Rybarski, Skarbowość Polski w dobie rozbiorów, Kraków 1937, s. 9-18, 70-71; G. Bałtruszajtys, Sadownictwo Komisji Skarbowych w sprawach handlowych i przemystowych (1764-1795), Warszawa 1977, s. 34-57; a także J. Dygdała, Toruń wobec Komisji Skarbu Koronnego w poczatkach panowania Stanistawa Augusta (1764-1768), Acta Universitatis Nicolai Copernici, Historia, t. 20: 1997, s. 81-89. 
beczek miodu Pana Wese [!], kupca toruńskiego, na komorze Rokitnica zatrzymanych, od konfiskaty uwolniwszy, za przemytę [!] dwoiste cła opłacenie naznaczyła, talarów zaś cztery, jeżeli się wzięte być pokazały, powrócić nakazała" ${ }^{29}$. Komisja zajmowała się zresztą tą sprawą chyba nieco wcześniej, bo już 24 października 1767 r. zatwierdziła decyzję superintendenta prowincji celnej mazowieckiej (a właściwie to mazowiecko-kujawskiej) dotyczącą zapłaty podwójnego cła „od miodu na komorze Rokitnica zabranego"30; najprawdopodobniej dotyczyło to właśnie miodu zakupionego przez Johanna Weesego.

Niestety, memoriał Gereta nie zachował się w aktach Komisji Skarbu Koronnego. Z podjętej przez Komisję decyzji wynikałoby, że wspomniany incydent wydarzył się na komorze celnej w Rokitnicy, gdzie w związku z próbą uniknięcia opłacenia cła skonfiskowano 6 beczek miodu należącego do Johanna Weesego, a przy okazji (zapewne podczas rewizji) zabrano woźnicom 4 talary (równowartość 32 złp). Komora celna rzeczywiście znajdowała się w miejscowości nazywającej się obecnie Rokitnica Wieś, położonej $15 \mathrm{~km}$ na południowy wschód od Brodnicy ${ }^{31}$. List brodnickiej Rady wyraźnie jednak świadczy, że celnicy umieścili wówczas swój posterunek w podmiejskiej karczmie. Wiemy zresztą, że tzw. obserwatorium celne, podporządkowane komorze celnej w Rokitnicy, zostało utworzone już wczesną jesienią 1765 r. na terenie wsi Michałowo, obecnym przedmieściu Brodnicy, położonym na lewym brzegu Brdy, wzdłuż drogi do Górzna. Wywoływało to awantury, a nawet dochodziło do starć między mieszczanami a urzędnikami celnymi ${ }^{32}$. Jest rzeczą prawdopodobną, że

${ }^{29}$ Biblioteka Książąt Czartoryskich w Krakowie (dalej cyt. BCzart.), rkp. 813, Zbiór diariuszów transactorum na sesjach ekonomicznych Komisji Skarbu Koronnego a die 1 Martii 1765 ad 31 Decembris 1767, s. 931/932, rezolucja z 2 XI 1767.

${ }^{30}$ Ibid., s. 922/923, rezolucja Komisji Skarbu z 24 X 1767.

${ }^{31}$ Komora celna w Rokitnicy nie występuje wprawdzie w wykazie komór prowincji mazowiecko-kujawskiej z 1767 r. ani z 1774 r., ale musiała już wówczas funkcjonować. Pojawiła się dopiero w wykazie z 1779 r. jako jedna z 22 komor należących do prowincji mazowieckiej. Obsługiwało ją trzech urzędników - pisarz, regent i substytut (zastępca pisarza) oraz kilkunastu strażników (celników), zob. T. Korzon, Wewnętrzne dzieje Polski za Stanistawa Augusta (1764-1794), t. 4, Kraków-Warszawa 1897, s. 119-112.

32 J. Dygdała, Brodnica w dobie Rzeczypospolitej szlacheckiej (1466-1772), [w:] Brodnica. Siedem wieków miasta, red. J. Dygdała, Brodnica 1998, s. 132. 
w październiku 1767 r. celnicy z Michałowa przenieśli się jeszcze bliżej miasta i zakwaterowali się w miejskiej, przydrożnej karczmie. Pobierane w Michałowie cło utrudniało kontakty handlowe brodniczan, ale też i okolicznej szlachty, z ziemią dobrzyńską i Mazowszem. Dlatego też na sejmiku generalnym Prus Królewskich odbywającym się w dniach 7-12 września 1767 r. wstawiono do instrukcji dla posłów na sejm punkt, w którym domagano się zniesienia komór celnych na granicy prowincji pruskiej z Koroną. Oczywiście miano tu na myśli właśnie posterunek celny w podbrodnickim Michałowie ${ }^{33}$.

Komisja Skarbu Koronnego okazała w tym przypadku pewną dozę pobłażliwości, bo zwolniła skonfiskowane już 6 beczek miodu, zobowiązując tylko Weesego do uiszczenia cła w podwójnej wysokości. Możliwe, że okoliczności tej konfiskaty nie były całkowicie jasne. Nadgorliwość, a czasem i prywata urzędników celnych wywoływały wówczas sporo skarg i Komisja niekiedy musiała swych funkcjonariuszy dyscyplinować, a nawet karać3 ${ }^{34}$. Inna rzecz, że Komisja nie zawsze była tak łaskawa jak w przypadku Weesego, gdyż uprzednio zaakceptowała decyzję superintendenta prowincji mazowieckiej o konfiskacie 14 krów i 3 wołów zatrzymanych na tejże komorze w Rokitnicy, a nieco później zdecydowała się skonfiskować aż 23 beczki miodu niejakiego pana Grabowskiego, których przemyt uznała za dowiedziony ${ }^{35}$.

Johann Weese nie był jednak w pełni zadowolony z decyzji Komisji Skarbu Koronnego i ponownie zwrócił się do Rady z prośbą o interwencję w jego sprawie. Rezydent Geret dostał odpowiednie polecenie i 12 listopada $1767 \mathrm{r}$. donosił swym mocodawcom, iż w sprawie podwójnego cła, które ma uiścić Weese, będzie mógł coś zrobić dopiero następnego dnia po południu, gdyż obecnie jest zajęty załatwianiem innych pilnych zleceń Rady. Dodał ponadto, że na razie Komisja Skarbu i tak nie załatwia spraw administracyjnych, gdyż zbiera się tylko na posiedzeniach sądowych. Z listu Gereta wynikałoby, że celni-

\footnotetext{
33 J. Dygdała, Życie polityczne Prus Królewskich u schyłku ich zwiazku z Rzeczapospolita w XVIII wieku. Tendencje unifikacyjne a partykularyzm, Warszawa-PoznańToruń 1984, s. 217

${ }^{34}$ T. Korzon, op. cit., t. 4, s. 143-145.

${ }^{35}$ BCzart., rkp. 813, s. 923, 945, rezolucje Komisji Skarbu Koronnego z 24 X i 14 XI 1767
} 
cy skonfiskowali (obok miodu?) także mąkę przeznaczoną dla Weesego $^{36}$. Nie ulega wątpliwości, że Geret przedłożył Komisji drugi memoriał w tej sprawie. 14 listopada Komisja Skarbu Koronnego „na memoriał J. Pana Gerret [!], sekretarza toruńskiego, rezolucję dała, iż do dawniejszej na jego memoriał, pod dniem 2 miesiąca teraźniejszego wypadłej rezolucji referuje się" ${ }^{37}$. Oznaczało to, że Komisja podtrzymuje swoją poprzednią decyzję.

Niezmordowany Geret raz jeszcze zwrócił się do Komisji Skarbu Koronnego, dowodząc, że konfiskata miodu należącego do Johanna Weesego wynikła z nieporozumienia, a więc nie powinien on opłacać karnego, podwójnego cła. Tym razem przedłożenia toruńskiego rezydenta poskutkowały i 17 listopada 1767 r. otrzymał on rezolucję Komisji, z której wynikało, iż Weese ma ostatecznie zapłacić tylko zwyczajne, pojedyncze cło. Powiadomił o tym oczywiście Radę Torunia ${ }^{38}$. Sprawa jest jednak o tyle dziwna, że w aktach Komisji nie ma wzmianki o tej trzeciej już rezolucji w sprawie Weesego. Można tylko przypuszczać, iż uznano tę kwestię za tak drobną, że nie wpisano jej do protokołu obrad Komisji i tylko ustnie polecono któremuś z niższych urzędników powiadomić pisarza komory celnej w Rokitnicy, iż wystarczy, gdy Weese opłaci pojedyncze cło za skonfiskowany mu uprzednio miód. Nawet jeżeli tak rzeczywiście było, to na przykładzie transportu miodu dla Weesego trzeba przyznać, że Komisja była bardzo drobiazgowa i niezwykle skrupulatnie zajmowała się napływającymi do niej sprawami. Zauważono to zresztą w dotychczasowej literaturze ${ }^{39}$.

Cała ta awantura dostarcza nam niezbitego dowodu, że Johann Weese sprowadzał półprodukty do produkcji pierników, to jest miód i mąkę, z dość odległych od Torunia stron. Fakt zatrzymania dwóch wozów z ładunkiem przeznaczonym dla Weesego na posterunku celnym w Michałowie pod Brodnicą może świadczyć, że jechały one od strony Górzna w ziemi dobrzyńskiej. Znajdował się tam duży kompleks lasów rozciągających się od Górzna do Lidzbarka Welskiego

\footnotetext{
${ }^{36}$ APTor., Kat. II, 3364, s. 727, S. L. Geret do Rady Torunia, Warszawa 12 XI 1767.

${ }^{37}$ BCzart., rkp. 813, s. 945/946, rezolucja Komisji Skarbu Koronnego z 14 XI 1767.

${ }^{38}$ APTor., Kat. II, 3364, s. 739, S. L. Geret do Rady Torunia, Warszawa 19 XI 1767.

${ }^{39}$ Zob. R. Rybarski, op. cit., s. 18.
} 
(obecnie Górznieńsko-Lidzbarski Park Krajobrazowy). Zapewne to właśnie tam znajdowały się barcie, skąd wybierano miód. Odległość między Brodnicą a Toruniem wynosi około $65 \mathrm{~km}$, a między Brodnicą a Górznem nieco ponad $20 \mathrm{~km}$. Oznaczałoby to, że wozy wysłane z Torunia po miód i mąkę dla Weesego musiałyby łącznie przebyć około $170 \mathrm{~km}$. Cała ta wyprawa musiała się jednak Weesemu opłacać.

W dotychczasowej literaturze przyjmuje się datę śmierci Johanna Weesego na rok $1796^{40}$. Tymczasem $\mathrm{z}$ ksiąg metrykalnych nowomiejskiej gminy ewangelickiej wynika, że zmarł on na puchlinę wodną (,Wassersucht”) w wieku 43 lat, przed 9 marca 1775 r., kiedy odbył się jego pogrzeb na nowomiejskim cmentarzu św. Katarzyny ${ }^{41}$. To nieporozumienie wzięło się prawdopodobnie z faktu, że w $1796 \mathrm{r}$. zmarła jego żona Dorota (Dorothea) Konkordia Weese, primo voto Schreiber. Nie ma wątpliwości, że po zgonie Johanna Weesego zakład piernikarski przez prawie 20 lat prowadziła Dorota (Dorothea), mająca, jako wdowa po dwóch mistrzach piernikarskich, odpowiednie doświadczenie. Może dopiero w 1790 r. zaczął jej pomagać starszy syn Johann Gottfried, który 14 sierpnia tego roku uzyskał tytuł mistrza piernikarskiego. Ostatecznie zakład przejął jej młodszy syn Andreas Michael Weese, który odbył staż czeladniczy w Norymberdze, a 8 lutego 1793 został mistrzem piekarnikarskim w Toruniu ${ }^{42}$. Obaj synowie, Johann Gottfried i Andreas Michael, podobnie jak trzeci, młodo zmarły Ernst Gottlieb, urodzili się przed 1769 r., kiedy to jako dzieci zostali wpisani do regestru (przyszłych) uczniów cechu piekarzy i ciastkarzy ${ }^{43}$. Dorothea Konkordia Weese zmarła przypuszczalnie w styczniu 1796 r., bo już 1 lutego jako właściciel domu przy obecnej ul. Królowej Jadwigi 20A jest odnotowany jej syn Andreas Michael Weese ${ }^{44}$. On też prowadził dalej, z sukcesami, firmę piernikarską Weese ${ }^{45}$.

${ }^{40}$ Zob. J. Kucharzewska, op. cit., s. 22, 27, tabela 2, s. 1.

${ }^{41}$ APTor., EGWN, t. 88, s. 215.

42 J. Kucharzewska, op. cit., s. 27, tabela 2, s. 1.

${ }^{43}$ APTor., Kat. IV, t. 6 nlb, Register der Lehrknechte..., wpis z 19 IV 1769.

${ }^{44}$ Informacja Krzysztofa Mikulskiego na podstawie APTor., Spis akt gruntowych Sądu Obwodowego w Toruniu, NM 12 (działka nr 11).

${ }^{45}$ A. Semrau, op. cit., s. 131-135; J. Kucharzewska, op. cit., s. 27-32. 


\section{Bibliografia}

\section{Źródła}

Archiwum Państwowe w Toruniu:

Akta Ewangelickiej Gminy Wyznaniowej Nowomiejskiej, t. 77

Akta miasta Torunia

Katalog II, I 54, I 55, księgi przyjęć do prawa miejskiego.

Katalog II, 3364, 3365, korespondencja rezydentów miasta Torunia na dworze królewskim, 1767.

Katalog II, XVI, 4, 19, 20, 21, księgi pogłównego 1763, 1764, 1767, 1769.

Katalog III, 5028, świadectwo dobrego urodzenia Gottfrieda Wehse, Gdańsk 5 XII 1714.

Katalog IV, t. 6, Regestr uczniów cechu piekarzy i ciastkarzy z XVIII w.

Biblioteka Książąt Czartoryskich w Krakowie, rkp. 813, Zbiór diariuszów transactorum na sesjach ekonomicznych Komisji Skarbu Koronnego a die 1 Martii 1765 ad 31 Decembris 1767.

Publikacje

Bałtruszajtys G., Sadownictwo Komisji Skarbowych w sprawach handlowych i przemystowych (1764-1795), Warszawa 1977.

Dygdała J., Brodnica w dobie Rzeczypospolitej szlacheckiej (1466-1772), [w:] Brodnica. Siedem wieków miasta, red. J. Dygdała, Brodnica 1998, s. 105157.

Dygdała J., Polityka Torunia wobec władz Rzeczypospolitej w latach 1764 1772, Warszawa-Poznań-Toruń 1977.

Dygdała J., Toruń wobec Komisji Skarbu Koronnego w poczatkach panowania Stanisława Augusta (1764-1768), Acta Universitatis Nicolai Copernici, Historia, t. 20: 1997, s. 81-89.

Dygdała J., Urzędnicy miejscy Torunia. Spisy, cz. III: 1651-1793, Toruń 2002.

Dygdała J., Życie polityczne Prus Królewskich u schyłku ich związu z Rzeczapospolita $w$ XVIII wieku. Tendencje unifikacyjne a partykularyzm, Warszawa-Poznań-Toruń 1984.

Korzon T., Wewnętrzne dzieje Polski za Stanisława Augusta (1764-1794), t. 4, Kraków-Warszawa 1897.

Kucharzewska J., Historia rodziny Weese - fabrykantów toruńskich pierników i jej inwestycje budowlane w Toruniu, Torun 2017.

Mikulski K., Przestrzeń i spoleczeństwo Torunia od końca XIV do początku XVIII wieku, Torun 1999. 
Mikulski K., Pułapka niemożności. Społeczeństwo nowożytnego miasta wobec procesów modernizacyjnych (na przykładzie Torunia $w$ XVII i XVIII wieku), Toruń 2004.

Rospond S., Słownik nazw geograficznych Polski zachodniej i północnej, Wrocław-Warszawa 1951.

Rybarski R., Skarbowość Polski w dobie rozbiorów, Kraków 1937.

Semrau A., Die Thorner Pfefferküchler, Mitteilungen des CoppernicusVereins für Wissenschat und Kunst zu Thorn, H. 46: 1938, s. 117-136. 